\title{
Asesmen Formatif Dalam Pembelajaran Inkuiri Model 5 E (Engagement, Exploration, Explanation, Elaboration, Evaluation) Untuk Meningkatkan Keterampilan Berpikir Kritis Berbasis WEB Pada Siswa SMA
}

\author{
Sukma Pradita ${ }^{\text {a, 1*}}$, Riskan Qadar ${ }^{\text {b, } 2}$, Laili Komariyah ${ }^{\text {c, } 3}$ \\ a Program Studi Pendidikan Fisika, Universitas Mulawarman, Jl. Muara Pahu Gunung Kelua Samarinda Kode Pos 75242 \\ 1 ditafrdth12@gmail.com* \\ *korespondensi penulis
}

\begin{abstract}
ABSTRAK
Penelitian yang mempunyai tujuan yaitu agar mendapati pengaruh asesmen formatif dalam pembelajaran inquiry model 5E untuk meningkatkan keterampilan berpikir kritis berbasis WEB pada siswa SMA. Jenis penelitian ini adalah jenis penelitian deskriptif kuantitatif. Metode yang digunakan dalam penelitian ini adalah penelitian yang bersifat pra-eksperimental design. Desain yang diterapkan yaitu one group pretest-posttest design. Populasi dalam penelitian ini adalah siswa kelas X SMA Negeri 1 Sendawar dengan jumlah sampel sebanyak 25 siswa pada kelas X MIPA 2. Teknik pengambilan data dengan menggunakan teknik Cluster Random Sampling dan teknik pengumpulan data menggunakan teknik tes. Pengumpulan data menggunakan teknis tes berupa 10 butir soal essai untuk mengetahui kemampuan berpikir kritis dan tes asesmen formatif berupa 3 butir soal essai. Hasil penelitian ini menunjukkan bahwa asesmen formatif dapat meningkatkan hasil belajar dengan nilai rata-rata tiga pertemuan berturut-turut sebesar 73, 81, dan 86 . Kemudian melalui penerapan pembelajaran inkuiri model 5E dapat meningkatkan keterampilan berpikir kritis dengan nilai gain 0,31 berada dalam kategori sedang.
\end{abstract}

Kata kunci : Asesmen Formatif, Inkuiri model 5E, Berpikir Kritis, Berbasis WEB

\begin{abstract}
This study aims to determine the effect of formative assessment in the 5E model of inquiry learning to improve WEB-based critical thinking skills in high school students. This type of research is a quantitative descriptive research. The method used in this research is a pre-experimental design. The research design used was one group pretest-posttest design. The population in this study were students of class X SMA Negeri 1 Sendawar with a total sample of 25 students in class X MIPA 2. The data collection technique used cluster random sampling and data collection techniques used test techniques. Data collection uses a technical test in have the shape of 10 essay items to determine critical thinking skills and a formative assessment test in the form of 3 essay questions to determine the improvement of learning outcomes. The results of this study indicate that formative assessment can improve learning outcomes with an average value of three consecutive meetings of 73,81 , and 86 . Then through the application of inquiry learning model $5 \mathrm{E}$ can improve critical thinking skills with a gain value of 0.31 in the medium category.
\end{abstract}

Key word: Formative Assessment, 5E Inquiry Model, Critical Thinking, WEB Based

\section{Pendahuluan}

Perkembangan pendidikan begitu cepat pada bidang ilmu pengetahuan dan teknologi sehingga mutu pendidikan juga harus ditingkatkan. Hal ini berkaitan dengan pengembangan kurikulum pendidikan sebagai upaya untuk meningkatkan mutu pendidikan (Islamiah, Satutik, \& Ni, 2018). Menurut Permendikbud No. 65 tahun 2013, kurikulum 2013 mengutamakan pada pendidikan karakter peserta didik yang dituntun dengan kaidah-kaidah pendekatan ilmiah dalam kegiatan pembelajarannya. Kurikulum pendidikan juga harus dapat menyuplai peserta didik dalam mengikuti pertumbuhan dan perkembangan di masyarakat dengan mempunyai keterampilan dalam berpikir tingkat tinggi. Dalam kegiatan pembelajaran perlu bagi siswa agar meningkatkan pemahaman konsep fisika tidak hanya menghafal rumus namun dapat memahami konsep dasar fisika agar tidak merasa terbebani oleh soal fisika (Lasmana, 2020).

Salah satu upaya dalam meningkatkan kurikulum ialah perlunya sebuah asesmen atau penilaian. Terdapat beberapa jenis asesmen diantaranya adalah asesmen formatif, asesmen sumatif, asesmen kinerja, asesmen portofolio, asesmen proyek, asesmen sikap, dan asesmen diri. Pada penelitian ini 
akan menggunakan asesmen formatif yaitu penilaian yang dilakukan tenaga pendidik saat kegiatan pembelajaran disekolah sedang berlangsung. Asesmen formatif dapat dilakukan melalui tes tertulis maupun tidak tertulis untuk melihat sejauh mana pengetahuan siswa pada materi yang diajarkan (Nurjannah, 2017).

Model yang sejalan dengan asesmen formatif ialah inkuiri model 5E (Engagement, Exploration, Explanation, Elaboration, Evaluation) seperti yang kita ketahui kelebihan model inkuiri adalah semua kegiatan pembelajaran lebih tersentralisasi pada peserta didik sehingga dapat mengembangkan konsep dari dalam diri, membuat saling berinteraksi satu sama lain, mendapatkan pengalaman secara langsung dan kerjasama dalam sebuah kelompok (Rodriguez, Kelli, \& Jason., 2019). Dengan menanamkan asesmen formatif ke dalam model 5E dapat merangsang rasa ingin tahu, membangun konsep awal dari penyelidikan, mengembangkan konsep dan prosedur ilmiah, menerapkan konsep, menilai pemahaman peserta didik atau umpan balik (Keeley, 2017). Keunggulan model ini adalah dalam pembelajaran lebih terpusat pada siswa yang mengembangkan pengetahuannya, meningkatkan motivasi siswa dalam belajar fisika sehingga siswa menjadi lebih aktif, menumbuhkan sikap keilmiahan siswa dan pembelajaran menjadi lebih berfaedah. Selain itu, dapat mencegah peserta didik dari metode yang kurang baik seperti menghafal.

Satu diantara kegiatan berpikir yang diwajibkan ialah berpikir kritis, dikarenakan dengan berpikir kritis siswa membuat keputusan dengan menggunakan penalaran yang berdasarkan alasan atau bukti yang kuat. Keterampilan ini ialah sebuah kemampuan yang mengimplementasikan teori dan konsep fisika, menguraikan hipotesis dan sudut pandang mengikuti data yang ada, kemudian menggambarkan dan menyimpulkan hasil tafsiran (Handayani, 2017).

Hal yang menarik dalam penelitian ini ialah pendidik mengusahakan melakukan inovasi model pembelajaran agar siswa yang pasif menjadi lebih aktif melalui pendekatan ilmiah dan memunculkan generasi muda yang mampu memecahkan masalah secara efektif dengan kemampuan berpikir kritis melalui model yang diterapkan. Karena keterampilan berpikir kritis memerlukan latihan, praktik secara langsung, dan kesabaran (Baiq, 2017). Selain itu pendidik dalam menyampaikan materi harus menggunakan metode yang tepat karena keberhasilan pendidik dalam mengajar tergantung oleh metode yang digunakan (Nano, 2021).

Permasalahan yang muncul disekolah sehingga perlu dilakukan penelitian yaitu siswa memandang pelajaran fisika sulit karena materi yang diberikan membosankan sehingga membuat siswa menjadi kurang aktif dalam kegiatan pembelajaran, sulit menyelesaikan beberapa persoalan dan membuat siswa tidak dapat menyelesaikan tantangan yang sulit kedepannya karena hanya mengikuti penyampaian secara langsung dari pendidik saja tanpa menggali ilmu lebih jauh. Seperti sejumlah penelitian terkini yang menunjukkan permasalahan ini perlu diselesaikan seperti yang dilakukan oleh Selvia pada tahun 2020 hasil yang diperoleh sangat baik dengan melakukan penelitian ini dapat menjadi solusi bagi permasalahan permasalahan tersebut.

Kegiatan yang dilaksanakan melalui penerapan pembelajaran inkuiri model $5 \mathrm{E}$, dalam proses pembelajaran ini akan meningkatkan kemampuan peserta didik menjadi seseorang yang berpikir kritis dengan pemikiran seperti seorang ilmuan karena dengan model ini peserta didik lah yang menjadi pusat pembelajaran dan menjadi seperti ilmuan dalam menemukan sesuatu hal yang baru dari hasil penyelidikan dengan pendekatan ilmiah yang dilakukan dan pada tahap akhir dari model ini juga sesuai dengan asesmen formatif dimana guru memberikan tes agar melihat sampai dimana wawasan siswa.

Setelah di amati melalui proses kegiatan belajar mengajar yang sudah dilaksanakan oleh guru fisika selama mengajar di SMA Negeri 1 Sendawar. Sekolah ini sudah mengembangkan model inkuiri dalam proses kegiatan pembelajaran namun, dalam kegiatan belajar mengajar ini masih kurang efektif untuk mengembangkan serta melatih kemampuan berpikir kritis siswa, bahkan siswa masih cenderung hanya mengikuti arahan oleh guru tanpa memiliki rasa ingin tahu yang lebih mendalam untuk 
menggali konsep-konsep fisika yang terdapat saat melakukan pembelajaran tersebut sehingga menurut peneliti disekolah ini memerlukan inovasi baru yang dapat diterapkan. Dari itu, penulis tertarik agar di SMAN 1 Sendawar mengalami perubahan yang bagus dalam berpikir kritis. Melalui siklus 5 E dapat membangkitkan pemahaman siswa berdasarkan lingkungan, sikap, kemampuan dan pengalamannya. Siswa dapat memilah informasi yang disediakan dan dapat menetapkan informasi yang lebih memikat perhatian yang selanjutnya akan diterjemahkan otak secara aktif dan memperjelas kesimpulan sesuai informasi yang sudah tersimpan (Sari, 2017). Untuk mendukung pendidik menciptakan suasana yang menyenangkan dapat menerapkan pembelajaran berbantuan internet salah satunya dengan menggunakan Zoom Presentation yang efisien menjadikan suasana kelas menjadi menarik dan dapat dilakukan kapanpun dan dimanapun.

Dampak positif yang diharapkan peneliti dengan berhasilnya melakukan penelitian ditempat ini dengan hasil yang baik dapat memberikan pengaruh baik terhadap peserta didik seperti lebih teratur untuk melakukan latihan dan lebih terampil dalam meningkatkan keterampilan berpikir kritis setelah diterapkan asesmen formatif pada setiap kegiatan pembelajaran, dapat memecahkan sendiri permasalahan sehari-hari yang memerlukan proses berpikir dan tidak terpaku pada rumus melainkan dapat mengembangkan rumus tersebut dari konsep fisika yang telah dipelajari dan dibuktikan sendiri kebenarannya melalui penelitian ini. Karena siswa yang berpikir kritis akan menentukan jalan terbaik dalam menghadapi persoalan dan mampu bersikap rasional (Yuliana, 2020)

Pertanyaan yang tumbuh dalam penelitian ini adalah "Bagaimana pengaruh asesmen formatif dalam pembelajaran inkuiri model $5 \mathrm{E}$ untuk meningkatkan keterampilan berpikir kritis berbasis web pada siswa SMA ?"

\section{Metode}

Jenis yang diterapkan yaitu deskriptif kuantitatif menggunakan metode pra-eksperimental design yang bertujuan untuk mendapatkan hubungan sebab-akibat dan pengaruh faktor-faktor dalam suatu kondisi tertentu. Populasinya ialah SMA Negeri 1 Sendawar Kabupaten Kutai Barat.

Data hasil dari penilaian pretest-posttest diterapkan agar melihat peningkatan sesudah menerapkan model. Pretest dilakukan untuk menilai kemampuan siswa sebelum diterapkan model inkuiri 5E dan posttest diberikan untuk menilai setelah diterapkan model.

Pada penelitian ini, menerapkan teknik analisis data antara lain:

1. Analisis Asesmen Formatif

Asesmen formatif dilaksanakan selama proses pembelajaran dengan model inkuiri 5E. Untuk mengetahui perbedaan nilai asesmen formatif yang diterapkan untuk setiap pertemuan. Penilaian asesmen formatif menggunakan rumus sebagai berikut.

$$
\text { Nilai Asesmen Formatif }=\frac{\text { skor perolehan }}{\text { skor maksimum }} \times 100
$$

a. Rata-rata

Nilai rata-rata yang diterapkan adalah nilai hasil penyelesaian soal pada LKPD. Penggunaan mean berhubungan dengan asesmen formatif yang akan ditinjau untuk tiap pertemuan. Rumus mean yang digunakan adalah:

$$
\bar{x}=\frac{\sum x}{n}
$$

b. Persentase

Untuk mengetahui persentase nilai asesmen formatif siswa digunakan rumus:

$$
\mathrm{P}=\frac{\text { nilai siswa }}{\text { nilai maksimum }} \times 100 \%
$$




\section{Analisis Kemampuan Berpikir Kritis Peserta Didik}

Kemampuan siswa berpikir kritis dapat diukur melewati soal tes sebelum melakukan kegiatan pembelajaran (pretest) dan sesudah melakukan kegiatan pembelajaran (posttest). Analisis data yang akan digunakan adalah sebagai berikut:

a. Nilai Rata-rata Peserta Didik

Nilai yang diterapkan ialah nilai hasil pretest dan posttest. Rumus rata-rata yang diterapkan ialah :

b. Persentase

$$
\bar{x}=\frac{\sum x}{n}
$$

Adapun cara perhitungan nilai persentase adalah:

$$
\mathrm{P}=\frac{\text { skor Perolehan }}{\text { Skor Maksimal }} \times 100 \%
$$

3. Peningkatan Kemampuan Berpikir Kritis

Tingkat keberhasilan pretest-posttest untuk melihat tingkat kemampuan berpikir kritis dapat diidentifikasi dengan uji gain. Uji $\mathrm{N}$-Gain dapat dihitung dengan menerapkan rumus berikut:

$$
\mathrm{N}-\text { Gain }(\%)=\frac{\text { nilai posttest }- \text { nilai pretest }}{\text { nilai maksimum }- \text { nilai pretest }}
$$

\section{Hasil dan Pembahasan}

Setelah dilakukan penelitian dengan memberikan tes tertulis berupa uraian pada siswa kelas $\mathrm{X}$ MIPA 2 maka didapatkan hasil pretest dan posttest dengan nilai rata-rata 49 dan 66 . Untuk mengetahui apakah ada atau tidak pengaruh sebelum menerapkan asesmen formatif dalam pembelajaran inkuiri model $5 \mathrm{E}$ dan setelah diberikan model tersebut. Pada hasil belajar dan kemampuan berpikir kritis siswa kelas X MIPA 2 SMA Negeri 1 Sendawar, sehingga hasil uji-t tersebut dapat dilihat pada tabel 1 .

Tabel 1. Nilai Hasil Uji-T

\begin{tabular}{clcccc} 
Paired & Pretest- & Rata-rata & SD & t & sig \\
\cline { 3 - 6 } Samples Test & Posstest & 16,26 & 13,73 & $-5,921$ & 0,0000
\end{tabular}

Berdasarkan tabel 1 uji-t tersebut didapatkan t-hitung adalah -5,921 diatas dengan jumlah sampel 25 siswa dan nilai signifikansi lebih rendah dari 0,05 maka bisa diambil kesimpulan bahwa ada perbedaan signifikan antara hasil pretest dan posttest.

Penelitian ini dilakukan dengan memberikan pretest terlebih dahulu untuk mengukur hasil belajar awal mula, berikutnya peserta didik diberi perlakuan berupa dengan asesmen formatif dalam pembelajaran inkuiri model 5E. Setelah diberi perlakuan dengan mengaplikasikan model pembelajaran tersebut, kemudian diberikan soal posttest untuk memperkirakan hasil belajar akhir setelah mendapatkan perlakuan.

Penelitian ini yang dilakukan di SMA Negeri 1 Sendawar selama 3 kali pertemuan, dimana setiap pertemuan dilakukan sekitar 3 jam pelajaran (3x45 menit) di kelas X MIPA 2. Pada pertemuan yang pertama siswa diberikan pretest dan pada pertemuan terakhir siswa diberikan posttest. Kemudian selama 3 kali pertemuan setelah pembelajaran siswa juga diberikan soal asesmen formatif agar mengetahui sampai dimana pemahaman setelah dilakukannya pembelajaran dengan mengggunakan menerapkan asesmen formatif dalam model inkuiri 5E.

Pada pembelajaran inkuiri model 5E terdapat beberapa tahapan pembelajaran diantaranya dalam tahap engage merupakan tahap dimana siswa dibimbing dalam menemukan masalah dari materi gerak lurus. Peneliti memberikan beberapa contoh terkait gerak lurus yang dapat memacu siswa pada suatu 
permasalahan yang harus dipecahkan. Siswa mulai menemukan beberapa masalah terkait gerak lurus. Beberapa siswa sudah mulai mengajukan pertanyaan terkait materi bahkan ada yang memberikan pendapat mereka mengenai beberapa contoh dalam materi gerak lurus sehingga saat mengawali materi siswa sudah mengetahui apa yang menjadi permasalahan yang harus dipecahkan nanti. Pada tahap explore siswa berkelompok untuk melakukan percobaan sehingga mereka memperoleh beberapa konsep yang bisa diterapkan untuk menyelesaikan masalah. Dalam berkelompok siswa melakukan pendekatan secara ilmiah sehingga ditemukanlah beberapa konsep dalam gerak lurus untuk memecahkan masalah.

Pada tahap explain semua kelompok yang melaksanakan percobaan mempresentasikan dan mengkomunikasikan data yang telah mereka peroleh. Dari penyampaian presentasi ini siswa banyak mendapat wawasan terkait konsep-konsep yang mereka temukan dalam percobaan. Setelah siswa mendapatkan beberapa konsep, pada tahap elaborate siswa mengerjakan soal dan mengembangkan hasil yang mereka peroleh untuk menyelesaikan permasalahan tersebut. Kemudian terakhir pada tahap evaluate siswa diberi lagi tes individu asesmen formatif untuk mengetahui sudah sampai dimana pemahaman siswa terkait materi yang sudah dipelajari sehingga peneliti dapat memperbaiki strategi apabila masih terdapat kekurangan agar pembelajaran menjadi lebih baik kedepannya.

Instrumen tes yang diterapkan berupa 10 soal uraian. Tes ini yang diterapkan untuk memperkirakan kemampuan berpikir kritis. Kemudian menggunakan soal asesmen formatif yang berupa soal essai sebanyak 3 soal, untuk melihat peningkatan hasil belajar peserta didik karena melalui asesmen formatif menjadi acuan pendidik untuk memperbaiki metode pembelajaran menjadi lebih maksimal.

Berdasarkan hasil yang diperoleh melalui pretest dan posttest mengalami peningkatan seperti pada hasil pretest diperoleh nilai rata-rata sebesar 49,28 sedangkan posttest diperoleh nilai rata-rata sebesar 65,54. Pada pretest hasil belajar dan berpikir kritisnya diperoleh 2 siswa dalam kategori baik 8\%, 4 siswa kategori cukup 16\%, 7 siswa kategori kurang 28\%, dan 12 siswa kategori kurang sekali $48 \%$. Setelah diberi perlakuan posttest hasil belajar dan berpikir kritis yang diperoleh yaitu 2 siswa kategori baik sekali 8\%, 12 siswa kategori baik 48\%, 3 siswa cukup 12\%, 5 siswa kurang 20\%, dan 3 siswa kurang sekali $12 \%$. Selain data hasil posttest, hasil dari soal asesmen formatif juga mengalami peningkatan yang signifikan. Data yang diperoleh yaitu pada asesmen formatif pertemuan pertama rata-rata nilai siswa sebesar 72,92 dengan nilai terendah 48, dan nilai tertinggi 97. Pada asesmen formatif pertemuan kedua rata-rata nilai siswa sebesar 81,44 dengan nilai terendah 73 dan nilai tertinggi 98. Pada asesmen formatif pertemuan ketiga rata-rata nilai siswa sebesar 85,52 dengan nilai terendah 73 dan nilai tertinggi 99.

Perolehan pretest pada soal hitungan nomor 2 ada 3 siswa yang tidak dapat menjawab, soal konsep dan hitungan nomor 3 ada 3 siswa, soal hitungan nomor 4 ada 17 siswa, soal hitungan nomor 5 ada 12 siswa, soal hitungan nomor 7 ada 21 siswa, soal konsep nomor 8 ada 1 siswa, soal hitungan nomor 9 ada 3 siswa, soal konsep nomor 10 ada 9 siswa. Kemudian untuk perolehan posttest pada soal hitungan nomor 2 ada 1 siswa yang tidak dapat menjawab, soal hitungan nomor 4 ada 6 siswa, nomor 5 ada 2 siswa, nomor 7 ada 7 siswa. Dari 10 soal pada saat pretest terdapat 8 soal yang tidak dapat dijawab oleh beberapa siswa kemudian setelah diberi perlakuan dan kembali diberi soal yang sama sebanyak 10 nomor terjadi perubahan yaitu menjadi hanya 4 soal yang tidak dapat dijawab siswa. Hal ini menunjukan bahwa terjadi perubahan yang cukup signifikan meskipun masih terdapat beberapa soal yang tidak dapat dijawab oleh siswa namun hal ini menunjukan terjadi peningkatan selama pembelajaran berlangsung. Nilai selisih antara pretest dan posttest tidak terlalu jauh berbeda dikarena kan waktu yang diperlukan untuk memahami materi sebelumnya tidak banyak sedangkan pada pertemuan selanjutnya peneliti perlu melanjutkan materi namun tidak seluruh siswa bisa memahami pelajaran yang dahulu dengan baik. Seperti menurut Siswanto,domain kognitif bergerak ke atas dimulai dari pengetahuan, penguasaan, aplikasi, analisis, sintesis, dan evaluasi. Sehingga untuk 
menuju tingkatan berikutnya siswa harus dapat menguasai tingkatan sebelumnya. Pada penelitian sebelumnya yang dilakukan suci handayani tahun 2017 memperoleh nilai pretest 3,26 dan posttest 6,89 merupakan hasil yang cukup signifikan mengalami peningkatan. Pada penelitian tersebut dilakukan dengan tatap muka langsung berbeda dengan penelitian ini yang dilakukan secara online karena banyak dipengaruhi dari sejumlah faktor salah satunya ialah jaringan yang lemah dan kuota internet siswa yang terbatas. Hal inilah yang membuat penelitian ini belum mencapai tingkat maksimal.

Hasil penelitian dengan rata-rata pretest sebesar 49 dimana termasuk dalam kategori kurang kritis sehingga dapat dikatakan kemampuan berpikir kitis siswa termasuk dalam katagori rendah. Kemudian untuk nilai rata-rata posttest adalah 66 dimana termasuk dalam kategori kritis dapat dikatakan kemampuan berpikir kritis siswa setelah diberikan perlakuan termasuk dalam kategori tinggi. Peningkatan dari posttest terdapat 17 siswa yang yang memenuhi kategori cukup sampai sangat kritis yang disebabkan pada saat melakukan kegiatan pembelajaran mereka lebih aktif dalam mengindahkan apa yang dipaparkan oleh penulis saat memaparkan materi, aktif melakukan percobaan dan aktif dalam mengerjakan soal asesmen formatif. Tetapi tidak semua siswa terlibat aktif, sebagian siswa terkendala jaringan didaerah masing-masing bahkan tidak ada jaringan jadi beberapa siswa membutuhkan waktu saat mengirimkan tugas saat melakukan pembelajaran online. Kemudian 8 siswa yang belum mencapai kategori kritis dikarenakan pada saat berlangsungnya pembelajaran siswa ini jarang online pada saat kegiatan pembelajaran fisika atau kesulitan mendapat jaringan didaerahnya. Keberagaman karakter siswa, kondisi pembelajaran online dari daerah masing-masing saat pembelajaran berlangsung menjadi salah satu kendala yang cukup besar bagi peneliti dikarenakan sulit dilangsungkan proses belajar-mengajar yang efektif secara online.

Berdasarkan hasil pembelajaran yang dilakukan dengan menerapkan asesmen formatif menggunakan model inkuiri 5E pada tiga pertemuan mengalami peningkatan. Seperti pada pertemuan pertama hingga ketiga memiliki nilai rata-rata 73, 81, dan 86 dapat dilihat pada lampiran 12 halaman 127. Pada pertemuan pertama capaian kemampuan yang diperoleh siswa dalam menyelesaikan permasalahan pada tahap engage siswa sudah dalam kategori baik dapat mengetahui dan memahami permasalahan yang akan mereka pecahkan, namun pada tahap lainnya siswa masih belum mencapai kriteria. Pada tahap explore ada sebagian siswa yang masih belum aktif dalam menemukan beberapa konsep. Pada tahap explain siswa hanya menyampaikan data tanpa mengaitkan dengan konsep yang telah ada. Pada tahap elaborate siswa masih belum dapat mengerjakan soal sesuai konsep yang telah mereka explor sehingga hasil pemecahan masalahnya masih belum maksimal. Pada tahap evaluate juga belum maksimal dikarenakan siswa belum memahami bagaimana prosedur dalam pemecahan masalah yang benar dalam mengerjakan soal sehingga hasil kurang maksimal. Oleh karena itu, agar terdapat peningkatan pada pertemuan 2 peneliti lebih memaksimalkan pada 4 tahap explore, explain, elaborate, dan evaluate.

Pada tahap explore dan explain lebih dimaksimalkan lagi selama pembelajaran dengan mengefektifkan diskusi sehingga semua siswa terlibat aktif dalam berkelompok dan peneliti juga memberi penjelasan yang lebih mudah dipahami untuk memperkuat konsep yang telah diperoleh siswa sehingga pemahaman konsep siswa jauh lebih baik. Pada tahap elaborate dan evaluate peneliti lebih memaksimalkan pengembangan hasil yang telah diexplore sesuai konsep yang diperoleh agar lebih maksimal dan memberi pemahaman pada siswa mengenai prosedur dalam pemecahan masalah yang benar dalam mengerjakan soal agar hasil jadi lebih maksimal. Kemudian pada pertemuan kedua capaian kemampuan yang diperoleh siswa dalam pemecahan masalah pada tahap engage, explore, dan explain siswa sudah dalam kategori baik dapat mengembangkan konsep dan semua siswa dalam kelompok sudah lebih terlibat aktif dari sebelumnya, namun pada tahap elaborate dan evaluate siswa masih belum mencapai kriteria. Pada tahap elaborate dan evaluate siswa masih belum maksimal dalam mengaplikasikan konsep pada permasalahan yang ada untuk memecahkan masalah sehingga dalam 
pengerjaan soal masih belum maksimal meskipun sudah mengikuti prosedur pengerjaan soal berdasarkan yang konsep yang telah diexplore. Oleh karena itu, agar terdapat peningkatan pada pertemuan 3 peneliti lebih memaksimalkan lagi pada tahap elaborate dan evaluate. Untuk memaksimalkan pada tahap ini peneliti memberikan gambaran berupa penjelasan singkat terkait mengaplikasikan konsep tersebut dalam pemecahan soal, kemudian peneliti juga lebih memperhatikan kesulitan siswa sebelumnya dalam pengerjaan soal agar siswa dapat selalu melatih kemampuan pemecahan masalahnya. Kemudian pada pertemuan ketiga sudah terlihat bahwa pada 5 tahap tersebut sudah mengalami peningkatan yang signifikan dalam kategori baik meskipun belum mencapai kategori sangat baik.

Siswa sangat bersemangat dalam melaksanakan percobaan dalam setiap Lembar Kerja Peserta Didik (LKPD) meskipun percobaan tidak dilakukan di sekolah, sehingga melatih kreativitas siswa dan melatih kekompakkan kelompok dalam mengerjakan LKPD. Hal ini dapat diketahui dari beberapa persiapan yang telah dilaksanakan oleh peserta didik pada hasil percobaan yang dibuat. Selain itu peserta didik juga aktif dalam menyelesaikan tugas asesmen formatif. Peserta didik juga telah berusaha mengerjakan soal yang cukup rumit dengan membaca contoh soal yang mirip dengan soal tersebut kemudian peserta didik bisa menyelesaikannya.

Pembelajaran model inkuiri 5E menuntut siswa turut aktif untuk berpikir, mencari, membuktikan dan masih dibimbing oleh guru sehingga pengetahuan yang diperoleh siswa lebih tertanam dan akan lebih diingat siswa. Penerapan asesmen formatif juga memberikan waktu pada siswa agar dapat menggali dan mendapatkan sejumlah fakta, konsep, dan prinsip sehingga dalam pembelajaran online menjadi lebih optimal. Namun masih ditemukan berbagai kesulitan saat pembelajaran seperti koneksi internet yang tidak selalu baik saat pembelajaran dilangsungkan.

Pengembangan model ini masih biasa, oleh karena itu peneliti merekomendasikan untuk pengembangan model selanjutnya bisa lebih baik lagi. Hal yang wajib dikembangkan lagi ialah Penambahan materi yang lebih menarik berpacu pada kurikulum 2013 dan disertai contoh soal maupun latihan untuk menambah motivasi siswa dan melatih pemahaman dalam mengaplikasikan rumus dan konsep yang ada.

\section{Simpulan}

Berdasarkan hasil penelitian dan analisis data yang telah dilakukan di SMA Negeri 1 Sendawar pada kelas X MIPA 2, dapat disimpulkan bahwa dengan penerapan asesmen formatif dalam pembelajaran inkuiri model $5 \mathrm{E}$ pada siswa SMA mengalami peningkatan. Hasil penelitian ini menunjukkan bahwa asesmen formatif dapat meningkatkan hasil belajar karena kelas X MIPA 2 mengalami peningkatan selama pembelajaran 3 pertemuan pada pertemuan pertama nilai rata-rata sebesar 73, pertemuan kedua nilai rata-rata sebesar 81 dan pertemuan ketiga nilai rata-rata sebesar 86 . Kemudian melalui penerapan pembelajaran inkuiri model 5E dapat meningkatkan keterampilan berpikir kritis dengan nilai rata-rata pretest sebesar 49 dan posttest sebesar 66 termasuk dalam kategori kritis yang diperoleh melalui uji $N$-Gain dengan hasil 0,31 dalam kategori sedang.

Adapun saran pemanfaatan dan pengembangan produk lebih lanjut adalah dalam penelitian ini peneliti mendapat beberapa hambatan selama berlangsungnya penelitian. Adapun hambatannya seperti saat berlangsungnya kelas online, beberapa siswa tidak dapat hadir pada jam yang sama banyak yang belum online pada saat mulai pembelajaran dikarenakan kuota internet dan jaringan didaerah masing-masing. Diharapkan untuk penelitian selanjutnya peneliti lebih mempersiapkan kemungkinan yang dapat terjadi seperti kuota internet peneliti dapat memberitahukan siswa dari jauh hari agar saat mulai pembelajaran semua siswa dapat hadir pada jam yang sama, kemudian peneliti selanjutnya juga mempersiapkan penjelasan berupa video yang mudah dimengerti siswa apabila terkendala jaringan, jadi tidak ada siswa yang tertinggal materi. 


\section{Referensi}

Handayani, S. (2017). Pengaruh Model Pembelajaran Inquiry Berbasis Learning Cycle 5E terhadap Kemampuan Berfikir Kritis Siswa. Universitas Islam Negeri Maulana Malik Ibrahim.

Handayani, T. (2017). Pengaruh Pembelajaran Model Discovery Learning Terhadap Kemampuan Berpikir Kritis Siswa Kelas VII SMP Negeri 4 Natar Lampung Selatan Tahun Pelajaran 2016/2017. Universitas Islam Negeri Raden Intan Lampung.

Islamiah, A.F., Satutik, R ., \& Ni, N. S. P. V. (2018). Efektivitas Model Pembelajaran Problem Based Learning Berbantuan LKS Terhadap Kemampuan Berpikir Kritis Fisika Siswa SMAN 1 Lingsar Tahun Ajaran 2016/2017. Jurnal Kependidikan Fisika., 6.

Keeley, P. (2017). Embedding Formative Assessment Into the 5E Instructional Model. Journal Articles Science and Children, 55(4).

Lasmana, A., Qadar, R., \& Syam, M. (2020). Pengaruh Model Pembelajaran OIDDE Terhadap Kemampuan Berpikir Kritis Siswa Di SMAN 2 Berau Pada Materi Suhu Dan Kalor. Jurnal Literasi Pendidikan Fisika, 1(01), 11-18.

Nano, M.I., Syam, M., \& Haryanto, Z. (2021). Penerapan Model Pembelajaran Inkuiri Terbimbing Pada Materi Impuls Dan Momentum Di SMA Negeri 11 Samarinda. Jurnal literasi pendidikan fisika, 2(1), 63-72.

Nurjannah. (2017). Efektivitas Bentuk Penilaian Formatif Disesuaikan dengan Media Pembelajaran. Jurnal Parameter, 29(0216-26IX).

Rodriguez, S., Kelli, A., Jason, H., \& Syeda. A. . (2019). Making and the 5E Learning Cycle. The Science Teacher.

Sari, S. M. (2017). Pengaruh Model Siklus Belajar 5E Pada Praktikum Koloid Terhadap Hasil Belajar Siswa Kelas XI MIA SMA Negeri 2 Pontianak. Ar-Razi: Jurnal Ilmiah, 5(2503-4448).

Yuliana, E., Subagiyo, L., \& Zulkarnaen. (2020). Pembelajaran Fisika Berbasis Android Dengan Program Adobe Flash Cs 6 Untuk Meningkatkan Kemampuan Berpikir Kritis Dan Hasil Belajar Siswa SMA IT Granada Samarinda. Jurnal Literasi Pendidikan Fisika, 1(02), 105-114. 